\title{
Economic sustainability analysis of Gaushalas in selected districts of Telangana state
}

\author{
Siguram Rohith, Raju Pradeep, Muniandy Sivaram and Somasekaran Subash
}

Received: 06 April 2021 / Accepted: 01 October 2021 / Published online: 21 December 2021

(C) Indian Dairy Association (India) 2021

\begin{abstract}
In India, with the increasing cattle population the number of stray cattle has also been increasing. While indigenous cattle constitute a major portion of the total cattle population their proportion has been showing a declining trend. Gaushalas can serve as an alternative for housing the increasing stray cattle and also for preserving the indigenous germplasm. However, Gaushalas are functioning with insufficient funds mostly from donations and government grant. Hence, in this study, an attempt was made to undertake economic sustainability analysis of Gaushalas by covering 14 Gaushalas in select districts of Telangana state. The data was collected from Gaushalas for the period 2014 to 2019 using a semi structured interview schedule. It was found that the major source of income to Gaushalas was from donations ( 82.5 per cent) followed by income from sale of milk and milk products (12.9 per cent). The expenses of the Gaushalas mainly included feed and fodder cost (82.5 per cent) followed by veterinary and miscellaneous expenditure (6.7 per cent). The overall net income for all the Gaushalas was negative. The returns over variable cost were positive for almost all the Gaushalas indicating that the Gaushalas were able to meet their immediate expenses in the short run. Economic Sustainability Index (ESI) was computed which ranges from 0 to 1 using 5 indicators viz., net income per animal, returns over variable cost, self-sufficiency, dependency and percentage of productive
\end{abstract}

Southern Regional Station, ICAR- National Dairy Research Institute, Bengaluru-560030, Karnataka, India

Muniandy Sivaram ( $\square)$

Southern Regional Station

ICAR- National Dairy Research Institute, Bengaluru-560030

Karnataka, India

E-mail: sivaram.ndri@gmail.com animals. The values of ESI of the Gaushalas ranged from 0.302 to 0.457. Among14 Gaushalas 2 Gaushalas fell under low economic sustainability and rest 12 Gaushalas were under medium economic sustainability category. A significant positive relationship was found between income diversification and sustainability of the Gaushalas $(r=0.73, \mathrm{P}<0.01)$. So, there is a need to diversify income sources such as income from sale of milk, milk products and other by-products.

Keywords: Breed conservation, Cow slaughter, Indigenous cattle, Stray cattle, Unproductive cattle

\section{Introduction}

India is blessed with rich livestock diversity. Livestock sector plays a major role in Indian agrarian economy. Livestock sector accounts for 4.2 per cent of the total Gross Value Added (GVA) and 28.6 per cent of GVA for agriculture sector (GoI, 2020). About 62 percent of the marginal farmers were associated with livestock and 17 per cent of their total income came from the livestock sector (Das et al. 2020). The total cattle population in India has reached to 192.49 million in the year 2019 from 190.90 million in 2012 (GoI, 2012 \& 2019). The major portion of cattle in India constitutes indigenous cattle up to 73.8 per cent of the total population as against 26.2 per cent of crossbred cattle. While the population of crossbred increased by 26.9 per cent from 2012 to 2019 the indigenous cattle population fell by 6.0 per cent. (GoI, $2012 \& 2019)$. The decreasing trend of indigenous population is a matter of serious concern as this may lead to loss of diverse genetic base of India (Yadav and Vij 2010; Mandi et al. 2018). The major reason for this problem is that farmers are showing preference to crossbred cattle over native cattle as the milk yield of crossbred cattle is more when compared to that of indigenous. When the milk yield of cattle decreases after 7 th or 8th lactation farmers abandon them. Thus, these unproductive and old cattle with no source of feed start wandering on farms and destroying crops. In urban areas, stray cattle are usually found eating plastic and other garbage which eventually leads to severe health problems or even death. These stray cattle also pose a threat to humans as they usually roam on highways and other roads leading to accidents. 
With further ban on slaughter of cow, the stray cattle population has been increasing. At present there are about 52,87,767 stray cattle in India and 36,366 stray cattle in Telangana state (GoI, 2019). With strict cultural and government restriction against slaughtering of cattle in almost all parts of India it is hard to control their population (Bijla and Singh, 2019). Sheltering stray cattle in Gaushalas can provide an alternative. Gaushalas in some states along with sheltering cattle are also taking up breeding activities to preserve the indigenous germplasm. Efficient management of Gaushalas is necessary as these institutions mostly depend on funds received from donations and government grants. However, Gaushalas face a number of issues like lack of funds, irregular support from government, lack of infrastructure, less space etc. (Bijla and Singh 2019). Hence, it is important to know the sustainability level of these institutes. Thus, in this study an attempt was made to assess the economic sustainability of Gaushalas in Telangana state.

\section{Materials and Methods}

\section{Study area and sampling}

Telangana is a state situated on the high Deccan Plateau, on the south-central part of the Indian Peninsula. It is India's eleventhlargest state and twelfth-most populous state with a total area of $112,077 \mathrm{~km}^{2}$ and 35,193,978 residents (Government of Telangana, 2015). The erstwhile state was split from the north-west portion of Andhra Pradesh on 2 June 2014 as the newly created 29th state with Hyderabad as its historic permanent capital. Telangana is largely rural, with roughly two-fifths of the state's population classified as urban. Hyderabad accounts for more than half of those in urban areas.

Telangana is gifted with huge livestock resources. It has a cattle population of 4.23 million head which consists of 0.61 million crossbred cattle (14.43 per cent) and 3.62 million indigenous cattle

Table 1 Distribution of cattle population across Gaushalas
(85.56 per cent) (GoI, 2019). Cattle in Telangana are protected under the act "The Telangana Prohibition of Cow Slaughter and Animal Preservation Act, 1977" which prohibits against slaughter of animals without certificate from competent authority (Government of Telangana, 2016). Since not many studies could be found regarding Gaushalas in Telangana this study can help understand their functioning from economic perspective.

The required data were collected from a sample of 14 Gaushalas located in southern Telangana spread across 10 districts. A list of sample Gaushalas selected for the study along with their respective cattle population is presented in Table 1 . The data regarding number of animals, their composition, funds generated by Gaushalas through donations, government grants, miscellaneous income and expenditure were collected from the records maintained by Gaushalas. Primary data for the study was collected on production and prices of milk and other products, expenditure incurred on green fodder, dry fodder, concentrates, labor and salaries of employees, and veterinary expenses using interview schedules from response persons in each of the selected Gaushala. The collected data were tabulated for five consecutive years from 2015 to 2019 and average value was taken for analysis.

\section{Analytical techniques}

\section{Ratio analysis}

Ratio analysis was attempted to analyze the economics of Gaushalas. The following ratios were worked out

$$
\begin{array}{ll}
\text { Operating Ratio } & =\frac{\text { Total operating expenses }}{\text { Gross Income }} \\
\text { Fixed Ratio } & =\frac{\text { Total fixed expenses }}{\text { Gross Income }} \\
\text { Gross Ratio } & =\frac{\text { Total expenses }}{\text { Gross Income }}
\end{array}
$$

\begin{tabular}{llllll}
\hline S. No & Gaushala & $\begin{array}{l}\text { Indigenous } \\
\text { cattle }\end{array}$ & $\begin{array}{l}\text { Crossbred } \\
\text { cattle }\end{array}$ & Buffalo & $\begin{array}{l}\text { Total cattle } \\
\text { population }\end{array}$ \\
\hline 1 & Mahbubnagar & 147 & 0 & 0 & 147 \\
2 & Gadwal & 150 & 0 & 0 & 150 \\
3 & Nagarkurnool & 350 & 0 & 0 & 350 \\
4 & Narayanpet & 105 & 0 & 0 & 105 \\
5 & Wanaparthy & 96 & 15 & 0 & 113 \\
6 & Medchal & 92 & 0 & 0 & 92 \\
7 & Ranga reddy-1 & 1050 & 0 & 0 & 1050 \\
8 & Ranga reddy-2 & 83 & 4 & 0 & 87 \\
9 & Ranga reddy-3 & 256 & 0 & 0 & 256 \\
10 & Hyderabad-1 & 500 & 100 & 0 & 600 \\
11 & Hyderabad-2 & 4280 & 202 & 222 & 4704 \\
12 & Hyderabad-3 & 50 & 2 & 0 & 52 \\
13 & Bhuvanagiri & 383 & 0 & 0 & 383 \\
14 & Medak & 1398 & 380 & 0 & 1778 \\
\hline
\end{tabular}




\section{Income diversification index}

Herfindahl-Hirschman Index (HHI) was computed to know the extent of income diversification of Gaushalas (Rhoades, 1993). HHI can be defined as the sum of the squares of the proportions of different sources of income. The degree of diversification can be measured using $H H I$ as follows

$$
\mathrm{HHI}=\mathrm{C}_{1}^{2}+\mathrm{C}_{2}{ }_{2}+\mathrm{C}_{3}^{2}+\mathrm{C}_{4}^{2}+\mathrm{C}_{5}^{2}+\mathrm{C}_{6}{ }_{6}+\mathrm{C}^{2}{ }_{7}+\mathrm{C}_{8}^{2}+\mathrm{C}_{9}^{2}
$$

Where,

$C_{1}, C_{2}, C_{3} \ldots \ldots \ldots \ldots \ldots C_{9}=$ Proportion of different sources of income to total income of Gaushalas

After calculation of HHI, Herfindahl Diversification Index (HDI) was calculated as:

$$
H D I=1-H H I
$$

Higher HDI value indicates higher the income diversification of the Gaushalas. Higher the income diversification of Gaushalas indicates higher the sustainability.

\section{Economic sustainability of Gaushalas}

The methodology of assessing the Economic Sustainability Index (ESI) was developed by Singh et al. (2019). In this study, the same methodology was followed for developing ESI.

\section{i. $\quad$ Net income per animal:}

Net income was obtained by deducting total expenses from gross income then dividing it by the number of cows in Gaushala. It has a positive effect on sustainability of Gaushalas. The Standard Animal Units were worked out as suggested by Sirohi et al. (2019).

Net Income $=\frac{\text { Gross Returns }- \text { Total cost }}{\text { Standard Animal Units }}$

\section{ii. Returns over variable cost}

If this indicator comes out to be positive, then it shows that particular Gaushala is able to meet its variable cost.

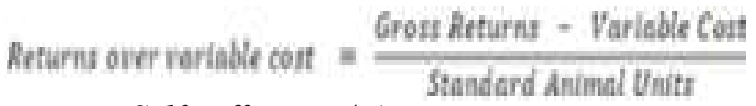 \\ iii. Self-sufficiency/Autonomy}

Proportion of income obtained from the sales of Gaushala products. It includes the income sources other than obtained from government grants and donations.

\section{iv. Dependency}

Dependency is calculated by computing the contribution of donations and government grants. For a Gaushala to be sustainable, this indicator should be less.

\section{v. Percentage of productive animals}

The productive animals include in-milk and pregnant cows, inmilk and non-pregnant cows, pregnant heifers and service bulls. It has a positive effect on sustainability of Gaushalas.

The data normalization was done to bring all the indicators to a common scale using Min-max technique.

$$
\begin{gathered}
I_{i}=\frac{X_{i}-\operatorname{Min} X_{i}}{\operatorname{Max} X_{i}-\operatorname{Min} X_{i}} \\
I_{i}=\frac{\operatorname{Max} X_{i}-X_{i}}{\operatorname{Max} X_{i}-\operatorname{Min} X_{i}}
\end{gathered}
$$

where $X_{i}=$ Value of $\mathrm{i}^{\text {th }}$ indicator

$i=1,2,3 \ldots \ldots \ldots n$ indicators

Differential weights were assigned to indicators following Singh et al. (2019) which was worked out based on expert opinions. The aggregate ESI was calculated as follows

$$
E S I=\frac{\sum W_{i} I_{i}}{\sum W_{i}}
$$

where

$I_{\mathrm{i}}=$ Normalized value of $i^{\text {th }}$ indicator

$W_{\mathrm{i}}=$ Weight given to each indicator from experts

$n=$ Number of indicators

ESI value varies from 0 to 1 . The Gaushalas were grouped into three categories based on their value of ESI, i.e. Gaushalas with ESI $<0.33$ were considered as less sustainable, $0.33<$ ESI $<0.66$ were considered as moderately sustainable, while Gaushalas with ESI $>0.66$ were considered as highly sustainable.

\section{Results and Discussion}

\section{Cattle population trends in Gaushalas}

Analysis of data regarding inflow and outflow of cattle in Gaushalas for the past 5 years showed that there was a continuous rise in inflow and outflow of cattle over the years (Fig.1) except in the year 2019. The rate of inflow was higher than the rate of outflow over the years. In 2019, both the inflow and outflow were lesser as data was collected till October, 2019. The composition of total cattle population in all the Gaushalas is shown in Fig. 2. 
Fig. 1 Trends in inflow and outflow of cattle in Gaushalas
Fig. 2 Age-sex composition of cattle population in Gaushalas
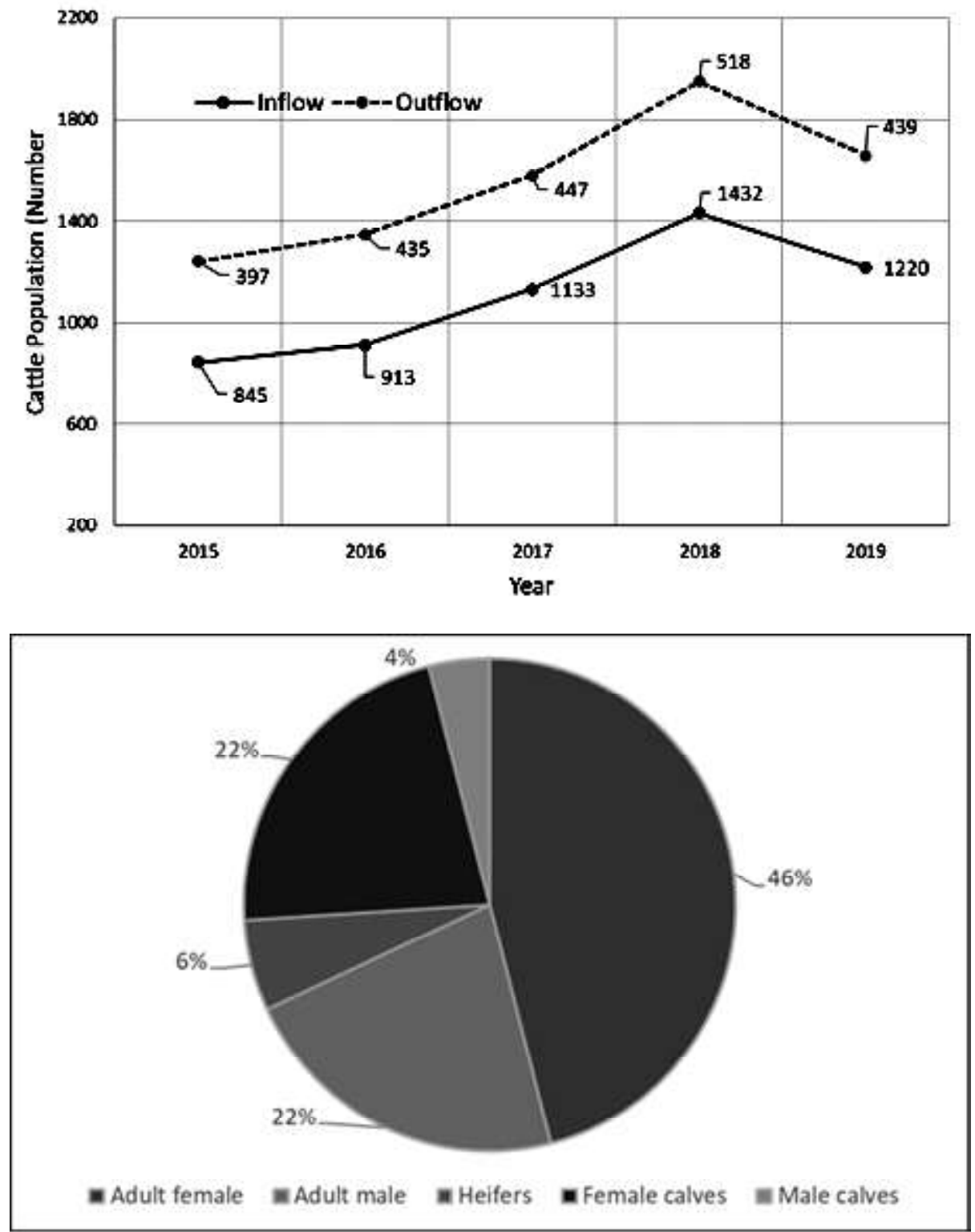

Adult females constitute major portion of total cattle population (46 per cent) followed by heifers ( 22 per cent).

\section{Income and expenses of Gaushalas}

The percentage share of income and expenditure of Gaushalas is shown in Fig. 3 and Fig. 4, respectively. It is seen that the major source of income to Gaushalas was from donations (82.46 per cent). Similar results were reported by Bijla and Singh (2019) in their economic study of Gaushalas in Haryana. It is observed that the monetary support from the Government or state animal husbandry departments was not extended to Gaushalas unlike other states like Karnataka or Haryana where monetary support is provided to registered Gaushalas annually. After donations, income from sale of milk and milk products, compost, cow dung, urine, phenyl and panchagavya contributed to a major portion of income of the Gaushalas (12.93 per cent). High dependence of Gaushalas on donations represented weak sustainability. Miscellaneous income which mainly constitutes money spent personally by owner of Gaushalas and income received from sale of grains, dead animals, sale of scrap, interest on deposits, tax rebate constituted the rest of income ( 4.59 per cent).

On the other hand, the expenses of Gaushalas mainly included feed and fodder cost contributing about 82.51 per cent followed by veterinary and miscellaneous expenditure ( 6.68 per cent). The miscellaneous expenditure includes minor repairs, fuel, festival, kitchen, utility, ropes, gunny bags, stationary, municipal taxes, insurance. Fixed costs namely labour expenses and cost of depreciation of assets constituted 5.78 and 5.01 per cent of the total expenditure respectively. 


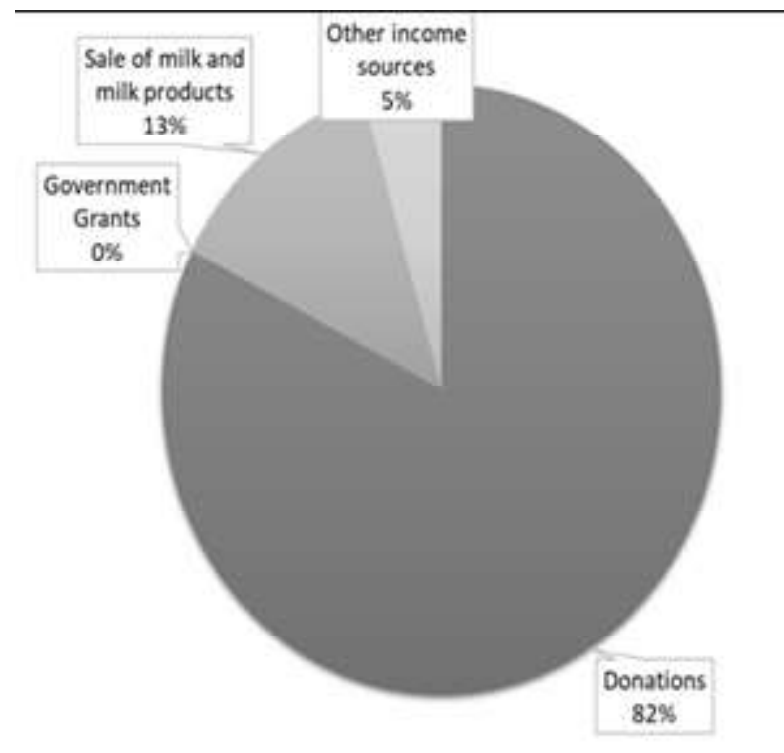

Fig. 3 Income sources of Gaushalas

\section{Net income across Gaushalas}

The average net income of Gaushalas for the period 2015 to 2019 is shown in Table 2. It reveals that most of the Gaushalas had negative net income except two Gaushalas in Gadwal and Hyderabad districts which had a positive net income of ₹ 71,800 and ₹ 12,700 per year respectively. The overall net income for all Gaushalas was negative with ₹ 1.17 lakh per annum. The reason for negative net income was lack of productive animals in Gaushalas. Most of the Gaushalas depended on donations and had very poor income generating sources. They also had high fixed expenses like depreciation of buildings and machinery etc. Large herd size was another reason for negative net income. Some Gaushalas management were against the idea of running Gaushalas for profits as their major objective is protecting stray cattle. Cultural significance towards indigenous cattle and negative opinion towards crossbred cattle was yet another reason for low productivity of Gaushalas. One Gaushala in Medak District had the lowest net income (negative ₹ 81.26 lakh per annum). The reasons for this again were low income, low level of income diversification and large herd size.

\section{Returns over variable cost}

When the returns are calculated only for variable costs, positive returns were obtained for most of the Gaushalas. Table 2 shows that returns over variable cost for all the Gaushalas. The positive returns over variable cost indicates that Gaushalas were able to meet their immediate expenditure requirements in the short run. Of all the Gaushalas Hyderabad-2 had the highest returns over variable cost (₹ 42,03,750/year). These high returns could be attributed to large donations received by the Gaushala. Gaushalas in Narayanpet, Wanaparthy, Medchal and Hyderabad had zero returns to variable costs. This indicates that these Gaushalas

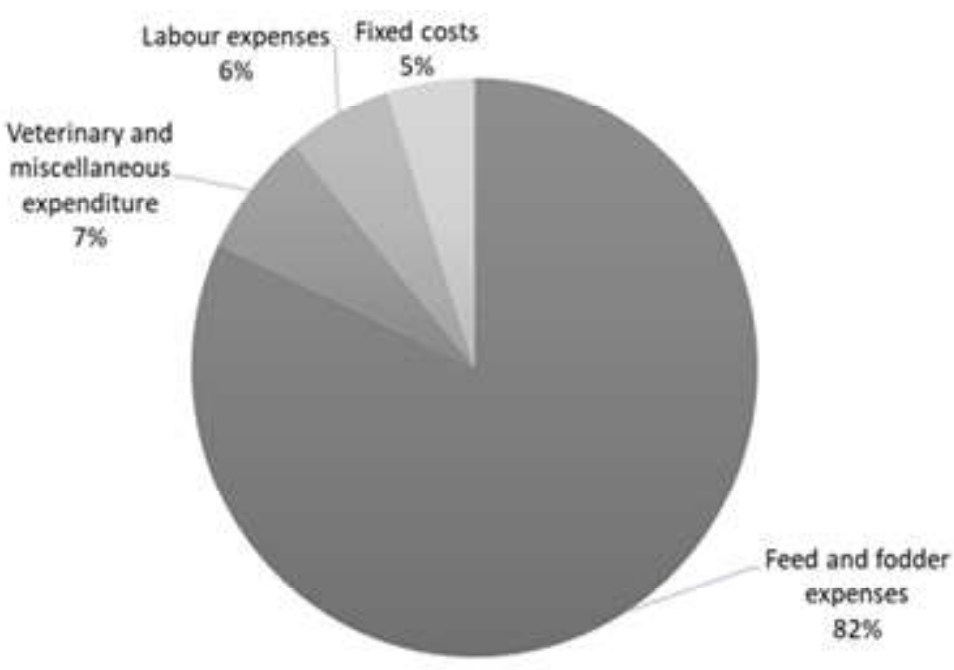

Fig. 4 Expenditure pattern of Gaushalas

were only able to meet their variable expenses and were on their breakeven point. They were located mostly in rural areas and outskirts of city making it hard to find donations.

\section{Ratio analysis}

Ratio analysis is an important tool to know about the profitability of the Gaushalas and to understand other financial implications (Table 3). These ratio measures indicate what proportion of gross income is spent for meeting different types of expenditure. Gross ratio values less than one indicate efficient functioning of enterprise. It was found that gross ratio for all the Gaushalas is more than one which indicates that Gaushalas were not performing efficiently i.e. they were unable to cover their total expenses with given gross income. Lower fixed ratio ranging from 0.02 to 0.15 (overall ratio 0.06 ) indicates that most part of the fixed expenses could be covered by prevailing income sources. Operating ratio is the most important ratio analysis which indicates the ability of Gaushala to meet immediate financial requirements in short run. The overall operating ratio of 0.98 indicates that 98 per cent of their income was spent covering only operating expenses. This shows that most of the Gaushalas in Telangana are not financially efficient.

\section{Income Diversification Index of Gaushalas}

HDI values range from 0 to 1 , zero being the lowest diversity and 1 indicating the maximum diversity. The HDI values of Gaushalas are presented in Table 4. Gaushalas in Ranga Reddy, Hyderabad and Bhuvanagiri were found to have the lowest HDI value of 0 indicating no diversity of income at all. The reason for their no diversity is because these Gaushalas were totally dependent on public donations and did not manage to have income source other than donations. The total dependence of Gaushalas on public donations makes them economically vulnerable in the long 
Table 2 Net income and returns over variable cost across Gaushalas

\begin{tabular}{llll}
\hline S. No & Gaushala & Net income (₹ 10,000/year) & $\begin{array}{l}\text { Returns over variable cost } \\
\text { (₹ 10,000/year) }\end{array}$ \\
\hline 1 & Mahbubnagar & -9.00 & 6 \\
2 & Gadwal & 7.18 & 20.8 \\
3 & Nagarkurnool & -2.94 & 4.3 \\
4 & Narayanpet & -3.66 & 0 \\
5 & Wanaparthy & -3.69 & 0 \\
6 & Medchal & -4.80 & 0 \\
7 & Ranga reddy-1 & -20.44 & 50.4 \\
8 & Ranga reddy-2 & -14.40 & 12.8 \\
9 & Ranga reddy-3 & -2.03 & 8.4 \\
10 & Hyderabad-1 & -15.45 & 40.8 \\
11 & Hyderabad-2 & 1.27 & 420.375 \\
12 & Hyderabad-3 & -8.13 & 0 \\
13 & Bhuvanagiri & -7.29 & 10.56 \\
14 & Medak & -81.26 & 105.2 \\
& Over all & -11.76 & 48.55 \\
\hline
\end{tabular}

Table 3 Financial ratios of Gaushalas

\begin{tabular}{lllll}
\hline S. No & Gaushala & Fixed ratio & Operating ratio & Gross ratio \\
\hline 1 & Mahbubnagar & 0.09 & 0.96 & 1.06 \\
2 & Gadwal & 0.15 & 0.77 & 0.92 \\
3 & Nagarkurnool & 0.04 & 1.23 & 1.26 \\
4 & Narayanpet & 0.03 & 1.00 & 1.03 \\
5 & Wanaparthy & 0.02 & 1.00 & 1.02 \\
6 & Medchal & 0.02 & 1.00 & 1.02 \\
7 & Ranga reddy-1 & 0.03 & 0.98 & 1.01 \\
8 & Ranga reddy-2 & 0.10 & 0.95 & 1.05 \\
9 & Ranga reddy-3 & 0.02 & 0.99 & 1.00 \\
10 & Hyderabad-1 & 0.07 & 0.95 & 1.02 \\
11 & Hyderabad-2 & 0.08 & 0.92 & 1.00 \\
12 & Hyderabad-3 & 0.11 & 1.00 & 1.11 \\
13 & Bhuvanagiri & 0.02 & 0.99 & 1.01 \\
14 & Medak & 0.04 & 0.98 & 1.02 \\
& Over all & 0.06 & 0.98 & 1.04 \\
\hline
\end{tabular}

run when the situations are not congenial. Maximum diversity was found in the case of Gaushala from Ranga Reddy (0.596) which received 57.27 percent of income from sources other than donations followed by Gaushala from Narayanpet $(0.585)$ which received 95.7 per cent of income from sources such as selling of milk, milk products, dung, and other miscellaneous sources. Though Narayanpet Gaushala received 95.7 per cent of its income from sources other than donations its HDI value is less because it received little income from donations and was more dependent on products produced within Gaushala making it vulnerable to production irregularities. On an average HDI of Gaushalas in Telangana was 0.262 indicating very low independence. A significant positive correlation was found between income diversification and sustainability of the Gaushalas $(r=0.73$, $\mathrm{P}<0.01)$. Similar findings were also reported by Bijla et al. (2019).

\section{Economic sustainability index of Gaushalas}

ESI values of all Gaushalas along with their respective values of Net Income per (Standard Animal Unit) SAU, returns over variable cost per SAU, autonomy, dependency and percentage productive animals are indicated in Table 4. The values of ESI for the Gaushalas ranged from 0.302 for Hyderabad-2 Gaushala to 0.47 for Hyderabad-3. Two Gaushalas, one from Hyderabad (0.30) and another from Ranga Reddy (0.32) fell under low ESI category (i.e. ESI $<0.33)$ and rest 12 Gaushalas under medium ESI category $(0.33<\mathrm{ESI}<0.66)$. None of the Gaushalas had ESI $>0.66$.

\section{Conclusions}

At present Gaushala is a new area of social concern with the increasing restrictions on slaughtering of cattle. The major source 
Table 4 Income diversity index and Economic sustainability index values of Gaushalas

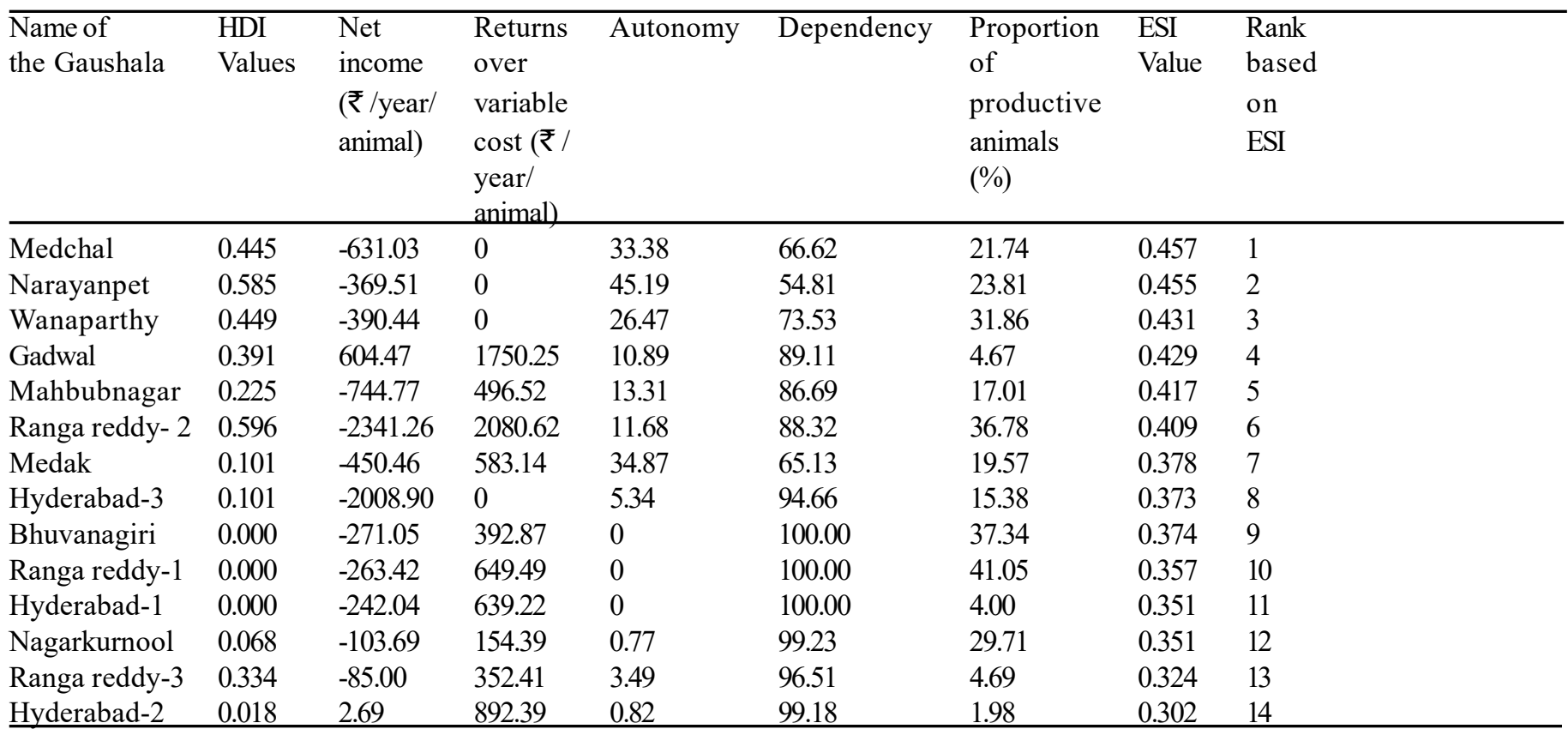

of income to Gaushalas was from donations followed by income from sale of milk and milk products. The Government should implement special schemes for Gaushalas and provide financial assistance to Gaushalas for their sustainability. The net income was found to be negative for most of the Gaushalas due to higher expenditure on feeding large number of animals and very low milk production. Hence, efforts should be made to provide good quality feed and fodder at reasonable prices which will help lowering the expenses of the Gaushalas. Though Gaushalas were able to meet their immediate expenses in short run they were not able to cover variable and fixed expenses completely. Space is yet another constraint with the increasing stray cattle. Government should provide land and other infrastructure to Gaushalas. A positive relationship between income diversification and economic sustainability of the Gaushalas indicates that there is a need to diversify income sources such as income from sale of milk, milk products and other by-products.

\section{Acknowledgements}

The first author thankfully acknowledges ICAR-National Dairy Research Institute, Southern Regional Station, Bengaluru for the scholarship.

\section{References}

Bijla S, Singh A (2019) Economic study of Gaushalas in Haryana: Functioning and Profitability. Indian J of Dairy Sci 72: 97-107

Bijla S, Singh A, Khalandar S, Sharma P (2019) An analysis of economic sustainability of Gaushalas in Haryana. Int J Livest Res 9: 171-188

Das ARR, Patnaik N (2020). Present Scenario and Role of Livestock Sector in Rural Economy of India: A Review. Int J Livest Res 10: $23-$ 30
GoI (2012) $19^{\text {th }}$ Livestock Census. All India Report. Ministry of Agriculture and Farmers Welfare, Department of Animal Husbandry, Dairying and Fisheries, Government of India, Krishi Bhavan, Delhi

GoI (2018) Basic Animal Husbandry and Fishery Statistics, 2018. Ministry of Agriculture and Farmers Welfare, Department of Animal Husbandry, Dairying, and Fisheries, Government of India, Krishi Bhavan, Delhi

GoI (2019) Provisional Key Results of 20th Livestock Census. Ministry of Agriculture and Farmers Welfare, Department of Animal Husbandry, Dairying, and Fisheries, Government of India, Krishi Bhavan, Delhi

GoI (2020) National Accounts Statistics, 2020. Ministry of Statistics and Programme Implementation, Government of India. http:// mospi.nic.in/publication/national-accounts-statistics-2020

Government of Telangana (2015) Statistical Abstract of Telangana, 201415. Directorate of Economics and Statistics, Hyderabad

Government of Telangana (2016) The Telangana Prohibition of Cow Slaughter and Animal Preservation Act, 1977. Adaptation of Laws Order, 2016 Issued in G.O.Ms. No. 45. Law (f) Department dated 01-06-2016 https://www.indiacode.nic.in/bitstream/ 123456789/ 8085/1/act_11_of_1977.pdf Accessed on 08 July 2020

Mandi K, Subash S, Singh NP, Koloi S (2018) An analysis of constraints faced by the Gaushalas in Karnataka State. J Entomol. Zool Stud 6: 787-791

Mandi K, Subash S, Devi MCA (2018) Strategies for conservation and improvement of indigenous cattle breeds in Gaushalas. Research Journal of Animal Husbandry and Dairy Science. 9: 20-25.

Rhoades SA (1993) The Herfindahl Hirschman index. Federal Reserve Bulletin. 79: 188

Singh A, Chauhan AK, Chandel BS and Kamboj ML (2019) A study on sustainability of Gaushalas in Haryana. Final Project Report (Project No. G-60), ICAR-National Dairy Research Institute, Karnal

Sirohi S, Chand P, Sharma D, Saxena R (2019) Estimation of bovine equalizing units in India: A regional perspective. Indian J Anim Sci 89: $1009-1013$

Yadav DK, Vij PK (2010) Inventorization of Gaushala resources and their use in breed improvement and conservation programmes. Indian $\mathrm{J}$ Anim Sci 80:343-345 